\section{A Community of Practice}

hy should I join the North Carolina Library Association?

What's in it for me?

These are frequently asked and perennially valid questions. As Past President of NCLA, I have spent countless hours thinking about them. In late October 2002, I was fortunate to be able to attend and participate in a panel discussion on "Portraying Yourself Online: A Discussion of Teaching Styles in Online Courses," with my East Carolina University colleagues from the School of Education, Diane Kester, Susan Colaric, and Sue Steinweg. Our panel was one of many learning experiences featured at the E-Learn 2002 World Conference on ELearning in Corporate, Government, Healthcare, and Higher Education held in Montreal, October 15-19, 2000, by the Association for the Advancement of Computing in Education.

I was excited about this opportunity but ambivalent about what an academic- librarian-turned-online-library-educator could contribute to the international higher education community. I was pleasantly surprised to find other librarians from the United States participating in this conference and to get to know colleagues in the distance instruction and education community from Appalachian State University. Imagine making friends with fellow Tar Heels right there in cosmopolitan Montreal! We all agreed that North Carolina is definitely in the vanguard of what is happening in the exciting community of cyberlearning.

On the Friday morning (October 18) before our afternoon presentation, I attended the keynote address "E-Learning and the Journey of the Self," given by e-learning consultant, Etienne Wenger. The concept that was woven throughout his entertaining presentation was that true learning takes place only in a community of practice - people who are dedicated to solving common problems, developing better products or services, and sharing results with other communities of practice, thus enhancing the body of knowledge that can be tapped by the global community.

While Wenger demonstrated his concept with examples of engineers working together to design more efficient windshield wipers, healthcare workers addressing the HIV-AIDS crisis, and Central American mayors banding together to learn from each other better ways to administer community services, I knew that there were local, state, regional, national, and even international communities of practice. I realized also that NCLA is a community of practice - North Carolina librarians, paraprofessionals, teachers, learners, library advocates, and friends dedicated to solving problems too great for the individual to handle.

NCLA is an organization where lovers of libraries can find kindred spirits who are also genuinely concerned about the provision of information services and resources to meet needs and desires of a wide array of communities, becoming better at what we love to do, discussing, debating, and eventually solving problems that have for too long challenged our communities of service. Participation in a community of practice is part and parcel of being a professional. That's why you should join the North Carolina Library Association! 